\title{
Analisis Kesulitan Guru dalam Penggunaan Media Pembelajaran Online di Sekolah Dasar
}

\section{Rose Winda ${ }^{1 *}$, Febrina Dafit ${ }^{2}$}

\author{
1,2 Universitas Islam Riau, Riau, Indonesia
}

\section{ART I CLE I N F O}

\section{Article history:}

Received May 22, 2021

Revised May 30, 2021

Accepted July 02, 2021

Available online July 25, 2021

Kata Kunci:

Kesulitan, Guru, Media

Pembelajaran Online

Keywords:

Difficulties, Teachers, Online

Learning Media

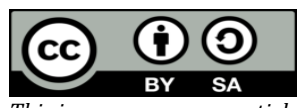

This is an open access article under the CC BY-SA license.

Copyright (C) 2021 by Author. Published by Universitas Pendidikan Ganesha.

\begin{abstract}
A B S T R A K
Pembelajaran daring mewajibkan guru menggunakan dan memanfaatkan media pembelajaran online. Akan tetapi, masih banyak guru yang mengalami kesulitan di dalam penggunaan media pembelajaran online, khususnya guru-guru tingkat Sekolah Dasar. Tujuan dilakukan penelitian ini adalah untuk mendeskripsikan media pembelajaran online yang digunakan guru serta mendeskripsikan kesulitan guru dalam penggunaan media pembelajaran online. Jenis penelitian ini adalah penelitian kualitatif deskriptif. Sumber data pada penelitian ini adalah tiga guru kelas, yaitu guru kelas I, IV dan guru kelas V. Teknik pengumpulan data yang digunakan adalah wawancara, observasi dan dokumentasi. Teknik analisis data menggunakan model Milles and Huberman dengan tahapan, reduksi data, penyajian data, dan penarikan kesimpulan. Hasil penelitian menunjukkan bahwa di dalam proses pembelajaran, guru menggunakan media pembelajaran online untuk melaksanakan kegiatan belajar mengajar. Media pembelajaran online yang digunakan guru yaitu WhatsApp, Google classroom dan Zoom. Di dalam penggunaan media pembelajaran online, guru mengalami kesulitan. Kesulitankesulitan guru dalam penggunaan media pembelajaran online yaitu Merancang media berbasis IT, Mengoperasikan media berbasis IT, Sarana dan Prasarana, dan Kreatifitas guru. Jadi, guru menggunakan media pembelajaran online seperti WhatsApp, Google Classroom dan Zoom. akan tetapi di dalam penggunaan media pembelajaran online, guru mengalami kesulitan. Kesulitan yang dialami guru yaitu guru kesulitan merancang media berbasis IT, mengoperasikan media berbasis IT, sarana dan prasarana yang tidak lengkap, serta yang terakhir adalah kreatifitas guru.
\end{abstract}

\section{A B S T R A C T}

Online learning requires teachers to use and utilize online learning media. However, there are still many teachers who have difficulty in using online learning media, especially elementary school teachers. The purpose of this research is to describe the online learning media used by teachers and to describe the difficulties of teachers in using online learning media. This type of research is descriptive qualitative research. The data sources in this study were three classroom teachers, namely class I, IV and class V teachers. The data collection techniques used were interviews, observation and documentation. The data analysis technique uses the Milles and Huberman model with stages, data reduction, data presentation, and drawing conclusions. The results of the study indicate that in the learning process, teachers use online learning media to carry out teaching and learning activities. The online learning media used by the teacher are (1) WhatsApp, (2) Google classroom, (3) Zoom. In the use of online learning media, teachers experience difficulties. The difficulties of teachers in using online learning media are (1) Designing IT-based media, (2) Operating IT-based media, (3) Facilities and infrastructure, (4) Teacher creativity. The conclusion of this study is that teachers use online learning media such as WhatsApp, Google Classroom and Zoom. However, in the use of online learning media, teachers experience difficulties. The difficulties experienced by teachers are that teachers have difficulty designing IT-based media, operating IT-based media, incomplete facilities and infrastructure, and the last is teacher creativity.

\section{PENDAHULUAN}

Pembelajaran pada hakikatnya adalah suatu proses mengatur, mengorganisasi lingkungan yang ada di sekitar peserta didik sehingga dapat menumbuhkan dan mendorong peserta didik melakukan proses belajar. Pembelajaran juga dikatakan sebagai proses memberikan bimbingan atau bantuan kepada peserta didik dalam melakukan proses belajar (Pane \& Dasopang, 2017). Pembelajaran yang baik meruoakan pembelajaran yang memberikan kesepatan kepada siswa untuk belajar lebih bermakna. Pembelajaran bermakna merupakan pembelajaran yang memberikan kesempatan kepada siswa untuk mendapatkan pengalaman dan mampu mengembangkan kemampuan emosi sosilanya (Bressington et al., 2018; Kostiainen et al., 2018). Untuk menghujudkannya bukanlah hal yang mudah apa lagi saat ini, 
pembelajaran sedang dilanda perubahan yang signifikan. Perubahan yang mengharuskan segala aktivitas yang berkaitan dengan pertemuan orang banyak harus di tunda bahkan di hentikan seperi seminar, seminar, lokakarya, koferensi dan pembelajaran yang harusnya tatapmuka harus menyesuiakan (Mishra et al., 2020; Oyedotun, 2020; Patricia, 2020; Sahu, 2020). Salah satu solusi pembelajaran yang dilakukan adalah dengan pembelajaran daring. Pembelajaran daring adalah salah satu solusi yang bisa dilakukan untuk mencegah terjadinya penyebaran covid-19 serta mengurangi kecemasan peserta didik dalam menghadapi perubahan kehidupan secara tiba-tiba (Hussein et al., 2020). Pembelajaran daring sangat berbeda dengan pembelajaran seperti biasa. Pembelajaran daring lebih menekankan pada ketelitian dan kejelian siswa dalam menerima dan mengolah informasi yang disajikan secara online. Pembelajaran daring merupakan sebuah pembelajaran yang dilakukan dalam jarak jauh melalui media berupa internet dan alat penunjang lainnya seperti telepon seluler dan komputer (Putria et al., 2020). Pembelajaran daring adalah pembelajaran dilakukan dengan bantuan internet baik secara sinkronus dan asinkronus yang memberikan kesempatan adanya interaksi peserta didik dengan sumber belajar baik pendidik/lingkungan serta teman sebayanya (Dong et al., 2020). Adanya pembelajaran online memberikan kesempatan kepada peserta didik untuk berbagi pendapat serta belajar lebih mandiri tanpa ada batas waktu dan ruang lebih bersifat fleksibel (Hwang et al., 2020; Kkese, 2020; Lage-Cala et al., 2020). Pembelajaran daring adalah sangat membutuhkan kemampuan pendidik dan peserta didik, karena dengan adanya kemampuan dalam menggunakan teknologi akan sangat membantu membuat suasana pembelajaran yang lebih kondusif, sehingga terbentuk interaksi social yang baik (Andel et al., 2020). Selain kemampuan tentunya pembelajaran online juga harus memperhatikan kondisi finansial dari peserta didik dan sarana dan prasarana yang menunjang pembelajaran online (Rusli et al., 2020). Jadi, dapat dikatakan bahwa pembelajaran daring akan memberikan peluang untuk tetap berlangsungnya pembelajaran serta tercapainya tujuan pembelajaran yang diinginkan. Untuk tercapainya proses pembelajarannya yang diinginkan tentunya memerlukan peran guru.

Guru merupakan pendidik yang profesional dengan tugas utama mendidik, mengajar, membimbing, mengarahkan, melatih, menilai, dan mengevaluasi peserta didik pada pendidikan anak usia dini jalur pendidikan formal, pendidikan dasar, dan menengah (Kamiludin \& Suryaman, 2017). Guru dituntut untuk memiliki kemampuan dasar yang diperlukan sebagai pendidik, pembimbing dan pengajar, dimana kemampuan tersebut tercermin pada kompetensi guru. Kompetensi guru menjadi penentu utama keberhasilan proses pembelajaran, termasuk di Indonesia. Guru akan berusaha agar kegiatan pembelajaran yang dilakukan berhasil. Guru berperan sebagai pengorganisasi lingkungan belajar dan sekaligus sebagai fasilitator belajar. Untuk memenuhi itu, maka guru haruslah memenuhi aspek bahwa guru sebagai: model, perencana, peramal, pemimpin, dan penunjuk jalan atau pembimbing ke arah pusatpusat belajar. Guru berperan untuk mengarahkan dan memberi fasilitas belajar kepada peserta didik (directing and facilitating the learning) agar proses belajar berjalan secara memadai, tidak semata-mata memberikan informasi. Bagaimana dan apapun bentuk strategi, model, dan media pembelajaran yang digunakan guru, sejatinya diorientasikan pada satu syarat utama, yaitu menarik sehingga menumbuhkan minat belajar siswa (Wahyono, 2020). Seperti saat ini, guru sangat perlu memahami dan mampu memilih media pembelajaran yang sesaui untuk digunakan.

Menggunakan media pembelajaran dalam proses belajar mengajar merupakan salah satu upaya untuk meningkatkan efektivitas serta kualitas dari proses pembelajaran yang pada akhirnya dapat meningkatkan kualitas hasil belajar peserta didik. Media pembelajaran merupakan segala sesuatu yang menyangkut software dan hardware yang dapat digunakan untuk menyampaikan isi materi ajar dari sumber pembelajaran ke peserta didik (individu atau kelompok), yang dapat merangsang pikiran, perasaan, perhatian, dan minat pembelajar sedemikian rupa sehingga proses pembelajaran (di dalam/ di luar kelas) menjadi lebih efektif (Jalinus, 2016). Media yang dipilih hendaknya yang benar-benar efektif dan efisien (Puspita et al., 2017). Penggunaan media harus disesuaikan dengan tujuan pembelajaran, materi, minat, kebutuhan, dan kondisi peserta didik (Aras, 2019; Lestari et al., 2018). Dengan memperhatikan hal-hal tersebut, media pembelajaran dapat menumbuhkan motivasi dan meningkatkan aktivitas pembelajaran (Setiawan, 2019). Begitu juga saat pembelajaran daring, pemilihan media online sangat menentukan proses pembelajaran. Penggunaan media pembelajaran online yang tepat, akan dapat membantu siswa dalam memahami materi pembelajaran yang disampaikan oleh guru pada saat pembelajaran daring (dalam jaringan). Akan tetapi pada kenyataannya, masih banyak guru yang mengalami kesulitan dalam penggunaan media pembelajaran online pada saat pembelajaran daring. Salah satunya yaitu, kemampuan guru dalam mengoperasikan IT (Information Technology). Masih banyak guruguru khususnya tingkat Sekolah Dasar yang tidak dapat mengoperasikan komputer atau laptop. Hal ini disebabkan minimnya kemampuan dan pemahaman guru mengenai IT, serta guru-guru yang sudah lanjut usia. Permasalahan yang di alami guru pada saat pembelajaran daring yaitu lemahnya penguasaan IT dan terbatasnya akses pengawasan terhadap peserta didik, dari peserta didik yaitu kurangnya motivasi dan 
konsentrasi dalam belajar, keterbatasan fasilitas pendukung, akses jaringan internet, sementara dari orang tua berupa keterbatasan waktu dalam menemani anaknya di saat pembelajaran daring (Wahyuningsih et al., 2021). Kondisi ini sesuai dengan kondisi yang dihadapi dilapangan, hasil analisis awal menyatakan bahwa bahwa pelaksanaan pembelajaran di SDN 109 Pekanbaru dilaksanakan secara daring (dalam jaringan). Hampir seluruh guru di SDN 109 Pekanbaru melaksanakan proses pembelajaran menggunakan aplikasi WA (WhatsApp). Dari hasil wawancara, juga didapatkan informasi bahwa di dalam proses pembelajaran guru memanfaatkan media pembelajaran seperti video pembelajaran yang di download dari situs youtube lalu membagikan kedalam group whatsapp. Akan tetapi, guru menyatakan bahwa guru mengalami kesulitan dalam penggunaan media pembelajaran online. Yang mana, tidak semua materi pembelajaran ada di situs youtube. Sehingga guru kesulitan dalam menyajikan media pembelajaran online. Untuk mengkaji lebih jelas tentang kondisi yang dialami oleh guru dalam penggunaan media pembelajaran online. Tujuan penelitian ini adalah untuk mendeskripsikan media pembelajaran online yang digunakan guru serta mendeskripsikan kesulitan-kesulitan guru dalam penggunaan media pembelajaran online di SDN 109 Pekanbaru.

\section{METODE}

Penelitian ini merupakan penelitian kualitatif dengan pendekatan deskriptif. Dafit \& Ramadan, (2020) menjelaskan bahwa salah satu karaktersitik penelitian deskriptif kualitatif yaitu untuk mengeksplor suatu permasalahan atau fenomena sosial serta mengembangkan pemahaman yang spesifik dari suatu fenomena yang diteliti. Subjek pada penelitian ini adalah 3 guru kelas, yaitu guru kelas I, IV dan guru kelas V di SDN 109 Pekanbaru. Teknik pengambilan subjek yaitu teknik purposive sampling. Teknik purposive sampling menurut Sugiyono, (2017) merupakan teknik pengambilan sampel data dengan pertimbangan tertentu. Pertimbangan tertentu ini, misalnya orang tersebut yang dianggap paling tahu tentang apa yang dibutuhkan oleh peneliti, atau mungkin dia sebagai penguasa sehingga akan memudahkan peneliti menjelajah obyek/situasi sosial yang diteliti. Pada penelitian ini, data didapatkan berdasarkan hasil observasi, wawancara, dan analisis dokumen. Peneliti melakukan wawancara dengan tiga guru kelas terkait penggunaan media pembelajaran online serta kesulitan guru dalam penggunaan media pembelajaran online. Setelah peneliti melakukan kegiatan wawancara, peneliti melakukan kegiatan observasi. Kegiatan observasi dilakukan secara daring (dalam jaringan) karena proses pembelajaran dilaksanakan secara daring. Kisi-kisi yang digunakan ditunjukkan pada table 1 dan 2. Peneliti masuk kedalam grup kelas II, IV dan grup kelas V, serta peneliti juga masuk kedalam google clasroom ketiga kelas tersebut. Ketika guru melakukan pembelajaran menggunakan media zoom peneliti juga ikut masuk kedalam zoom tersebut. Peneliti juga melakukan analisis dokumen seperti RPP, Silabus, Buku Guru dan Buku Siswa untuk mengkaji materi yang sedang dipelajari oleh guru dan siswa. Data yang telah dikumpulkan melalui teknik wawancara, observasi serta analisis dokumen selanjutnya di analisis. Pada penelitian ini, untuk menganalisis data peneliti menggunakan model Milles and Huberman dengan 3 tahapan yaitu reduksi data, penyajian data, dan penarikan kesimpulan.

Tabel 1. Indikator Media Pembelajaran Online

\begin{tabular}{cll}
\hline No & \multicolumn{1}{c}{ Indikator } & \multicolumn{1}{c}{ Sub Indikator } \\
\hline 1. & Media Pembelajaran Online & WhatsApp \\
& & Zoom \\
& & Google Classroom \\
& & Meet \\
& & Google Suite \\
2. & Berbasis IT & Memanfaatkan Teknologi Informasi \\
3. Sarana dan Prasarana & Komputer \\
& & Laptop \\
& & Handphone \\
4. & Multimedia & Jaringan Internet \\
& & Memadukan Teks, Audio, Animasi, Gambar, Grafik dan \\
\hline
\end{tabular}

Sumber : Herliandry ,(2020) 
Tabel 2. Kesulitan penggunaan media pembelajaran online

\begin{tabular}{lll}
\hline No & & Indikator \\
\hline 1. & Merancang media berbasis IT & \\
2. & Mengoperasikan media berbasis IT & \\
3. & Sarana dan Prasarana & \\
4. & Kreatifitas Guru & \\
\hline
\end{tabular}

Sumber : Alwi, (2017)

\section{HASIL DAN PEMBAHASAN}

Hasil

Pelaksanaan pembelajaran di SDN 109 Pekanbaru, selama peneliti mengumpulkan data dilapangan masih dilaksanakan secara daring (dalam jaringan). Berikut merupakan data hasil penelitian mengenai penggunaan media pembelajaran online serta kendala guru dalam penggunaan media pembelajaran online di SDN 109 Pekanbaru.

Tabel 3. Hasil Penelitian Penggunaan media pembelajaran online serta kesulitan guru dalam penggunaan media pembelajaran online.

\begin{tabular}{|c|c|c|c|}
\hline No & $\begin{array}{l}\text { Guru } \\
\text { Kelas }\end{array}$ & $\begin{array}{l}\text { Media } \\
\text { Pembelajaran } \\
\text { Online } \\
\end{array}$ & Kesulitan guru dalam penggunaan media pembelajaran online \\
\hline 1. & $\begin{array}{l}\text { Guru } \\
\text { Kelas I }\end{array}$ & WhatsApp & $\begin{array}{l}\text { 1. Tidak semua orang tua siswa memiliki handphone. } \\
\text { 2. Orangtua terkendala di jaringan dan kuota. } \\
\text { 3. Guru kesulitan menyampaikan materi kepada siswa, sehingga } \\
\text { guru hanya memberikan tugas kepada siswa. } \\
\text { 4. Tidak semua siswa mengumpulkan tugas yang dikirimkan guru } \\
\text { melalui WhatsApp Group. } \\
\text { 5. Guru kesulitan menyajikan materi kepada siswa selama proses } \\
\text { pembelajaran daring,karena tidak semua materi ada di situs } \\
\text { youtube sehingga guru hanya memberikan tugas kepada siswa. } \\
\text { 6. Guru kesulitan membuat media pembelajaran setiap harinya } \\
\text { yang sesuai dengan materi yang akan diajarkan. }\end{array}$ \\
\hline \multirow[t]{3}{*}{2.} & $\begin{array}{l}\text { Guru } \\
\text { Kelas } \\
\text { IV }\end{array}$ & WhatsApp & $\begin{array}{l}\text { 1. Tidak semua orangtua/siswa yang memiliki handphone dan } \\
\text { kuota. } \\
\text { 2. Guru terkendala di jaringan. } \\
\text { 3. Tidak semua siswa mengumpulkan tugas. } \\
\text { 4. Guru kesulitan membagikan materi melalui aplikasi WA, karena } \\
\text { tidak semua materi ada di situs youtube. }\end{array}$ \\
\hline & & Zoom & $\begin{array}{l}\text { 1. Guru belum menguasai penggunaan aplikasi zoom dengan baik. } \\
\text { 2. Tidak semua siswa atau orang tua siswa dapat mengoperasikan } \\
\text { zoom. } \\
\text { 3. Pada saat guru melakukan zoom, guru terkendala dijaringan. } \\
\text { 4. Guru kesulitan membuat media pembelajaran yang sesuai } \\
\text { dengan materi yang diajarkan hari ini. } \\
\text { 5. Guru kesulitan menyajikan materi pada saat pengunaan zoom. } \\
\text { Sehingga pada saat zoom, guru hanya meminta siswa untuk } \\
\text { membaca buku siswa. }\end{array}$ \\
\hline & & $\begin{array}{c}\text { Google } \\
\text { ClassRoom }\end{array}$ & $\begin{array}{l}\text { 1. Guru belum menguasi penggunaan google classroom dengan } \\
\text { baik. } \\
\text { 2. Disaat guru memberikan tugas di google classroom banyak } \\
\text { siswa yang tidak mengumpulkan tugas tepat waktu. } \\
\text { 3. Masih banyak siswa dan orang tua siswa yang tidak bisa } \\
\text { mengoperasikan google classroom. }\end{array}$ \\
\hline 3. & $\begin{array}{l}\text { Guru } \\
\text { Kelas V }\end{array}$ & WhatsApp & $\begin{array}{l}\text { 1. Tidak semua orangtua/siswa memiliki handphone. } \\
\text { 2. Jaringan yang tidak stabil. } \\
\text { 3. Saat diberikan tugas, masih banyak siswa yang tidak } \\
\text { mengumpulkan tugas. }\end{array}$ \\
\hline
\end{tabular}




\begin{tabular}{lccc}
\hline No & $\begin{array}{c}\text { Guru } \\
\text { Kelas }\end{array}$ & $\begin{array}{c}\text { Media } \\
\text { Pembelajaran } \\
\text { Online }\end{array}$ & Kesulitan guru dalam penggunaan media pembelajaran online \\
\hline
\end{tabular}

4. Guru hanya memberikan tugas melalui aplikasi WA.

5. Guru kesulitan menyajikan materi yang sesuai dengan materi yang akan diajarkan, hal ini dikarenakan tidak semua materi ada di situs youtube atau web lainnya.

6. Guru kesulitan menggunakan media pembelajaran yang cocok untuk pembelajaran hari ini.

Zoom 1. Guru belum menguasai penggunaan aplikasi zoom.

2. Tidak semua orangtua/siswa mampu mengoperasikan zoom.

3. Pada saat pelaksanaan zoom, guru terkendala di jaringan.

4. Pada saat zoom, guru kesulitan menyajikan materi dan membuat media pembelajaran setiap harinya.

Google 1. Guru belum menguasai penggunaan google classroom.

Classroom 2. Tidak semua siswa/orang tua siswa mampu mengoperasikan google classroom.

3. Pada saat guru memberikan tugas di google classroom hampir semua siswa tidak mengumpulkan tugas.

Berdasarkan hasil wawancara dan observasi dari bulan Juli sampai Agustus 2021, agar kegiatan belajar mengajar tetap dapat dilaksanakan meskipun tidak tatap muka, guru-guru di SDN 109 Pekanbaru menggunakan media pembelajaran online. Beberapa media online yang digunakan dalam proses pembelajaran. Pertama WhatsApp. Di dalam pelaksanaan kegiatan belajar mengajar di SDN 109 Pekanbaru, guru menggunakan WhatsApp sebagai sarana utama untuk melaksanakan proses pembelajaran. Berdasarkan hasil wawancara dan observasi guru-guru kelas di SDN 109 Pekanbaru menyatakan bahwa guru-guru lebih sering menggunakan WhatsApp sebagai alat untuk melaksanakan kegiatan belajar mengajar. Guru menggunakan aplikasi WhatsApp untuk menyampaikan informasi dan memberikan tugas kepada siswa. Di kelas tinggi, melalui aplikasi WhatsApp guru menyampaikan informasi kepada siswa terkait materi-materi yang akan dipelajari dan membagikan tugas kepada siswa. Sedangkan dikelas rendah guru menggunakan aplikasi WhatsApp untuk menyampaikan informasi kepada orang tua siswa, karena siswa kelas rendah belum bisa mengoperasikan atau menggunakan Handphone. Maka dari itu, guru kelas rendah menggunakan aplikasi WhatsApp untuk menyampaikan informasi kepada orang tua siswa untuk mengambil tugas di sekolah dan menyampaikan informasi lainnya. Hampir semua guru di SDN 109 Pekanbaru menggunakan aplikasi WhatsApp. Hal ini dikarenakan di dalam penggunaannya lebih mudah dibandingkan aplikasi lainnya. Melalui aplikasi WhatsApp inilah guru menyampaikan informasi dan memberikan tugas-tugas kepada siswa. WhatsApp merupakan aplikasi berbasis internet yang memungkinkan setiap penggunanya dapat saling berbagi berbagai macam konten sesuai dengan fitur pendukungnya (Rahartri, 2019). WhatsApp juga memiliki berbagai fitur yang dapat digunakan untuk berkomunikasi dengan bantuan layanan internet. Whatsapp merupakan platform pesan yang dapat digunakan dalam pembelajaran jarak jauh, dimana mahasiswa dikumpulkan disatu grup dan proses pembelajaran dilaksanakan secara pesan baik dengan tulisan, suara maupun gambar (Endah \& Romadhiyana, 2021; Kusuma \& Hamidah, 2020). Penggunaan media WhatsApp dalam proses pembelajaran memberikan dampak yang baik karena siswa. Penggunaan media WhatsApp dalam proses pembelajaran memberikan dampak yang baik bagi proses pembelajaran daring saat ini mengingat aplikasi WhatsApp mempunyai kelebihan yaitu penggunaan data yang lebih kecil dibandingkan dengan aplikasi yang lain, berkomunikasi dengan lebih dari 50 orang, dan biaya yang dihabiskan tidak terlalu banyak (Bakhtiyar, 2017), selain itu penggunaan WhatsApp lebih praktis, lebih mudah dipahami anak, lebih efektif kerena tidak membutuhkan banyak quota dalam proses pembelajaran serta alasan lain adalah lebih mudah dan semua orang tua wali murid dapat menggunakannya dan bukan hal yang asing (Anugrahana, 2020). Beberapa penelitian yang sudah dilakukan berkaitan dengan WhatsApp sebagai alat belajar daring. Penelitian yang menyatakan bahwa Implementasi whatsapp sebagai mobile learning dapat meningkatkan hasil belajar mahasiswa pada pokok bahasan pengenalan komponen elektronika (Pratama \& Yusro, 2016). Penelitian yang menyatakan media Whatsapp lebih efektif digunakan dalam meningkatkan hasil belajar daripada dengan pembelajaran dengan situs berbasis web Schoology (Muqsith \& Zainiyati, 2021). Penelitian yang menyatakan bahwa penggunaan WhatsApp dalam pembelajaran bahasa dipercaya mampu mendorong motivasi siswa yang mana pada akhirnya akan membuat mereka belajar kosakata secara efektif (Bakhtiyar, 2017). Jadi, berdasarkan jabaran tersebut dapat diakatakan bahwa adanya media WhatsApp dapat digunakan sebagai medai pembelajaran daring. 
Kedua Google Classroom. Berdasarkan hasil wawancara dan observasi di SDN 109 Pekanbaru, di dalam pelaksanaan pembelajaran khususnya di kelas tinggi, guru memanfaatkan media pembelajaran online yaitu google Classroom. Google Classroom merupakan media yang menyediakan kemudahan dalam pendistribusian materi pembelajaran maupun soal serta dapat digunakan sebagai sarana penilaian terhadap hasil kerja peserta didik dan melakukan interaksi dengan pengguna lainnya (Marharjono, 2020). Google Classroom (atau dalam bahasa Indonesia yaitu Ruang Kelas Google) adalah suatu serambi pembelajaran campuran yang diperuntukkan terhadap setiap ruang lingkup pendidikan yang dimaksudkan untuk menemukan jalan keluar atas kesulitan dalam membuat, membagikan dan menggolong-golongkan setiap penugasan tanpa kertas(Salamah, 2020). Guru memanfaatkan google classroom untuk membagikan tugas kepada siswa dan meminta siswa mengumpulkan tugas sesuai dengan waktu yang sudah ditetapkan. Kelebihan yang lain dari google classroom adalah Google Classroom terjangkau dan aman yang disediakan gratis untuk sekolah, lembaga nonprofit, dan perorangan serta tidak berisi iklan dan tidak pernah menggunakan konten pengguna atau data siswa untuk tujuan periklanan(Atikah et al., 2021). Dengan kelebihan yang dimiliki oleh google classroom menjadi pilihan dalam proses pembelajaran. Beberapa penelitian berkaitan google classroom, penelitian yang menyatakan bahwa erdapat pengaruh signifikan motivasi belajar mahasiswa setelah diterapkan pembelajaran google classroom (Nirfayanti \& Nurbaeti, 2019). Penelitian yang menyatakan bahwa media Google Classroom dan WhatsApp dapat meningkatkan hasil belajar siswa kelas XII Busana 2 SMK Negeri 3 Baubau (Amlin, 2021). Penelitian yang menyatakan bahwa Google classroom efektif digunakan pada mata pelajaran praktikum administrasi pendidikan karena mahasiswa dan dosen mudah untuk mengakses sesuai dengan kebutuhan perkuliahan (Rahmanto \& Bunyamin, 2020). Penelitian yang menyatakan bahwa Google classroom efektif diterapkan proses pembelajaran secara virtual (Bhimani, 2020). Serta penelitian yang menyatakan bahwa terdapat pengaruh positif antara penerapan e-learning berbantuan google classroom dan whatsapp group terhadap kemampuan pemahaman konsep (Amalia \& Puwaningsih, 2020). Jadi, dengan adanya google classroom proses pembelajaran daring akan lebih efektif sehingga tujuan pembelajaran yang diharapkan akan mampu dihujudkan.

Ketiga zoom, Di SDN 109 Pekanbaru, guru memanfaatkan zoom untuk menyampaikan materi kepada siswa. Guru menyatakan bahwa di dalam proses pembelajaran minimal seminggu guru 2 kali menggunakan aplikasi zoom untuk mengontrol kegiatan belajar siswa. Aplikasi zoom hanya digunakan di kelas tinggi, hal ini dikarenakan di kelas rendah tidak memungkinkan untuk guru melakukan zoom. Mengingat, siswa kelas rendah belum bisa mengoperasikan handphone maupun orang tua siswa yang tidak semua paham mengenai teknologi. Sehingga media zoom hanya digunakan dikelas tinggi seperti kelas III,IV,V dan kelas VI. Zoom merupakan sebuah media pembelajaran menggunakan video. Zoom meeting merupakan media yang dapat digunakan secara langsung dengan siapapun sehingga sangat cocok digunakan untuk pembelajaran jarak jauh di tengah pandemi ini (Marsiding, 2021). Aplikasi ini tidak hanya digunakan untuk pembelajaran saja tetapi bisa digunakan untuk urusan perkantoran maupun urusan lainnya. Platfrom ini gratis jadi dapat digunakan oleh siapapun dengan batas waktu empat puluh menit dan tidak ada batasan waktu jika akun kita berbayar. Dalam aplikasi Zoom Meeting ini kita bisa berkomunikasi langsung dengan siapapun lewat video. Oleh karena itu, memang cocok digunakan sebagai media pembelajaran(Haqien \& Rahman, 2020). Adanya media zoom berdampak positif terhadap proses pembelajaran, Zoom dapat mendukung pembelajaran jarak jauh, memudahkan anak didik untuk menyerap materi pembelajaran yang disampaikan pendidik karena lebih real timed an interkatif sebagai media pembelajaran(Ismawati \& Prasetyo, 2020). Kelebihan zoom antara lain media Zoom Cloud Meeting seperti fleksibilitas dalam proses perkuliahan, meningkatkan kedisiplinan dosen dan mahasiswa, dan beberapa fitur tambahan yang dapat menunjang kelancaran pelaksanaan perkuliahan(Mubarak et al., 2020). Jadi, adanya zoom akan berdampak positif terhadap proses pembelajaran.

Media pembelajaran yang digunakan guru adalah WhatsApp, Google Classroom dan Zoom. Hal ini sudah sejalan dengan pendapat Habibah, (2020) yang menyatakan bahwa banyak sekali teknologi media pembelajaran yang berbentuk platform yang dapat digunakan disetiap instansi pendidikan, pada tingkat sekolah maupun di perguruan tinggi untuk mengefektifkan proses pembelajaran yang dilakukan. Seperti Google Classroom, E-learning, YouTube, WAG, Edmodo, Zoom, Google meet dan platform lainnya yang mampu menjadi penunjang fasilitas belajar dari rumah. Hal yang sama juga dijelaskan oleh Herliandry (2020) yang menyatakan bahwa media pembelajaran online yang disarankan digunakan oleh guru untuk berlangsungnya proses pembelajaran dengan baik yaitu WhatsApp (WA), telegram, Zoom, Google Classroom dan ruang guru.

\section{Kesulitan guru dalam penggunaan media pembelajaran online}

Berdasarkan hasil wawancara dan observasi di SDN 109 Pekanbaru, guru menyatakan bahwa guru mengalami kesulitan di dalam penggunaan media pembelajaran online. Kesulitan-kesulitan yang 
dialami guru terkait penggunaan media pembelajaran online yaitu Pertama, merancang media berbasis IT. Berdasarkan hasil wawancara dan observasi, guru menyatakan bahwa kesulitan guru di dalam penggunaan media pembelajaran online adalah merancang media berbasis IT. Hal ini dikarenakan kemampuan guru untuk merancang media berbasis IT masih sangat rendah. Di dalam proses pembelajaran, guru hanya menggunakan dan memanfaatkan media atau materi yang sudah ada pada situs web seperti situs youtube. Guru mencari video atau materi yang ada di situs youtube. Kemudian guru membagikan kepada siswa. Salah satu kesulitan guru di SDN 109 Pekanbaru dalam penggunaan media pembelajaran online yaitu guru kesulitan merancang media berbasis IT. Di dalam proses pembelajaran, guru dituntut untuk menyajikan materi online, baik dalam bentuk video, teks, gambar dan sebagainya. Akan tetapi, masih banyak guru yang tidak bisa merancang media berbasis IT. Kebanyakan guru hanya menggunakan yang sudah ada, contohnya seperti materi yang ada di situs youtube. Menjelaskan bahwa kompetensi guru merupakan kemampuan seorang guru dalam melaksanakan kewajiban secara bertanggung jawab. Guru yang dinyatakan kompeten dibidang tertentu adalah seseorang yang menguasai kecakapan kerja atau keahlian selaras dengan tuntutan bidang kerja yang bersangkutan. Pekerjaan yang bersifat profesional adalah pekerjaan yang hanya dilakukan oleh mereka yang khusus dipersiapkan untuk itu dan bukan pekerjaan yang dilakukan oleh mereka yang karena tidak dapat memperoleh pekerjaan lain. Hal ini sesuai dengan pendapat Alwi, (2017) bahwa sebagian dari guru yang hanya terpaut kepada bantuan dalam penyediaan media pembelajaran padahal media pembelajaran dapat didesain dari berbagai sumber dalam berbagai bentuk sesuai dengan kebutuhan dan karakteristik materi ajar yang akan diajarkan. Selain itu beliau juga menambahkan bahwa apabila media pembelajaran sesuai dengan tuntutan kurikulum tidak ada satupun yang sulit diperoleh, maka membuat media pembelajaran sendiri dapat menjadi suatu keputusan yang tepat. Serta, Fauziah (2018) juga mengatakan bahwa agar seorang pendidik dalam menggunakan media pembelajaran dapat optimal dan efisien, setiap pendidik harus dapat memiliki pemahaman dan pengetahuan yang baik tentang media pengajaran.

Kedua, mengoperasikan media pembelajaran online. Berdasarkan hasil wawancara dan observasi, kesulitan guru selanjutnya adalah mengoperasikan media pembelajaran online. Di SDN 109 Pekanbaru, tidak semua guru dapat mengoperasikan media pembelajaran online dengan baik. Masih banyak guru yang belum bisa mengoperasikan media pembelajaran online. Khususnya, guru-guru yang sudah lanjut usia. Sehingga, proses pembelajaran daring (dalam jaringan) yang dilakukan guru di SDN 109 Pekanbaru hanya memberikan tugas kepada siswa. Setiap harinya guru hanya meminta siswa untuk mengerjakan tugas dan meminta siswa untuk mengumpulkan tugas tersebut. Hal ini dikarenakan belum semua guru dapat mengoperasikan media pembelajaran online dengan baik. Dari 3 guru kelas yang peneliti observasi, terdapat 2 guru kelas yang hanya dapat mengoperasikan media pembelajaran online menggunakan aplikasi WhatsApp. Sehingga pelaksanaan pembelajaran masih dapat dikatakan tidak efektif. Tidak dapat dipungkiri bahwa masih banyak guru yang tidak dapat mengoperasikan media berbasis IT. Hal ini dikarenakan kemampuan guru terhadap IT masih sangat rendah. Masih banyak kepala kepala sekolah dan guru - guru yang belum menguasai TIK. Padahal kepala sekolah selain dituntut memiliki kompetensi manajerial dalam hal mendayagunakan sumber daya sekolah untuk mengelola dan mengatur penggunaan fasilitas pendidikan secara efektif dan efisien serta dapat menempatkan personel yaitu guru dan karyawan dengan berdasarkan kompetensi dan kualifikasinya. Selain itu, kepala sekolah dan guru juga dituntut mampu menggunakan TIK dalam proses menejerial maupun pembelajaran sehingga dapat memvisualisasikan konsep-konsep belajar agar menjadi lebih menarik bagi siswa. Faktor penyebab guru kesulitan mengoperasikan media berbasis IT yaitu kurangnya pengetahuan guru tentang IT (laptop/komputer, infokus, printer, dan internet) disebabkan oleh faktor usia dan kesulitan dalam mencari file (Syaulan, 2018).

Ketiga, sarana dan prasarana. Kendala guru selanjutnya adalah sarana dan prasana yang tidak memadai, seperti tidak semua siswa memiliki handphone, dan tidak semua orang tua mampu membeli handphone. Sehingga sarana dan prasarana inilah yang menjadi kesulitan atau kendala utama guru di dalam penggunaan media pembelajaran online. Selain itu, jaringan juga termasuk di dalam kesulitan guru pada penggunaan media pembelajaran online. Pada saat guru melaksanakan proses pembelajaran masih banyak siswa yang terkendala di jaringan. Sehingga, guru hanya meminta siswa untuk mengerjakan tugas yang diberikan guru setiap harinya dan meminta siswa untuk mengumpulkan tugas tepat waktu. Pelaksanaan pembelajaran daring membutuhkan adanya fasilitas sebagai penunjang, yaitu seperti smartphone, laptop, ataupun tablet yang dapat digunakan untuk mengakses informasi dimanapun dan kapanpun. Di Indonesia sendiri, ada beberapa aplikasi yang disediakan pemerintah sebagai penunjang kegiatan belajar di rumah. Selain itu seorang pendidik dapat melakukan tatap muka bersama peserta didiknya melalui aplikasi yang dapat diakses dengan jaringan internet (Sourial et al., 2018). Namun beberapa kendala yang ada dalam pembelajaran daring membuat para peserta didik kurang berminat terhadap pembelajaran daring tersebut Sarana dan prasarana sangat menunjang berhasilnya kegiatan 
belajar mengajar pada saat pembelajaran daring. Ketika sarana dan prasarana tidak lengkap maka kegiatan belajar mengajar akan terhambar. Komponen yang sangat penting untuk menunjang dan mendukung keberhasilan pelaksanaan proses pembelajaran berlangsung adalah sarana dan prasarana (Rahayu \& Haq, 2020). Pembelajaran daring tidak terlepas dari pemanfaatan teknologi. Fasilitas teknologi yang mendukung pelaksanaan pembelajaran daring adalah pemanfaatan sistem informasi manajemen pendidikan. Sarana dan prasarana merupakan bagian terpenting dalam penerapan pembelajaran daring dikarenakan sistemnya menggunakan layanan internet, teknologi tersebut berupa smartphone dan laptop, biasanya kebanyakkan guru maupun orang tua lebih banyak menggunakan smartphone dibandingkan Laptop karena lebih praktis (Harahap et al., 2021). Jadi,

Keempat, Kreatifitas Guru, proses pembelajaran daring (dalam jaringan) guru dituntut untuk menyajikan materi pembelajaran. Guru yang kreatif akan menyajikan materi dengan sebaik mungkin, seperti salah satu contoh yaitu membuat video pembelajaran terkait materi yang akan diajarkan. Akan tetapi, di SDN 109 pekanbaru, guru tidak membuat video pembelajaran itu sendiri, melainkan guru mencari video pembelajaran dari sumber lain seperti di situs youtube dan sebagainya. Sehingga guru harus memilih video yang sesuai dengan tema dan materi yang akan diajarkan. Guru merasa repot dalam proses pembuatan video pembelajaran yang memakan waktu yang lama. Guru yang kreatif adalah guru yang mampu menyajikan materi dengan menarik. Guru kreatif adalah seorang pengajar yang memiliki kemampuan untuk mengembangkan ide-ide baru dan cara-cara bau dalam mendidik, mengajar,membimbing, mengarahkan, melatih, menilai dan mengevaluasi peserta didik (Oktiani, 2017). Akan tetapi, masih banyak guru yang tidak kreatif. Kebanyakan guru hanya sekedar mengajar dan memanfaatkan segala yang sudah ada. Salah satu masalah yang dihadapi dalam dunia pendidikan adalah menumbuhkan kreativitas guru (Pentury, 2017). Kreativitas guru dalam proses belajar mengajar mempunyai peranan penting dalam memotivasi belajar siswanya. Kreativitas diartikan sebagai kemampuan untuk menciptakan suatu produk baru, baik yang benar-benar baru sama sekali maupun yang merupakan modifikasi atau perubahan dengan mengembangkan hal-hal yang sudah ada. Salah satu yang mempengaruhi dalam proses belajar mengajar adalah guru, yang merupakan faktor eksternal sebagai penunjang pencapaian hasil belajar yang optimal. Kreativitas guru mempengaruhi motivasi belajar siswa, tidak hanya mengacu pada hal-hal yang berkaitan dengan proses pembelajaran semata seperti pemberian materi pembelajaran, penggunaan metode atau lainya, tetapi juga perwujudan perilaku guru sendiri yang luwes, komunikatif, menyenangkan, membimbing, kesejajaran dan lain sebagainya.

Pembelajaran daring memberikan dampak yang sangat signifikan terutama pada penggunaan teknologi dalam proses pembelajaran. Pembelajaran yang berlangsung menuntut kemampuan penggunaan teknologi dalam pelaksanaannya (Muskania \& Zulela MS, 2021). Agar kegiatan belajar mengajar tetap dapat dilaksanakan dengan baik, maka guru dituntut untuk menggunakan media pembelajaran online. Media pembelajaran online adalah suatu proses pembelajaran yang memanfaatkan teknologi informasi berupa komputer yang dilengkapi dengan sarana telekomunikasi (internet, intranet, ekstranet) dan multimedia (grafis, audio, video) sebagai media utama dalam penyampaian materi dan interaksi antara pengajar dan pembelajar (Putranti, 2013). Pembelajaran daring mengharuskan guru melek teknologi karena jika guru tidak mampu mengoperasikan IT, maka guru akan merasa kesulitan untuk melaksanakan pembelajaran daring dan menggunakan media pembelajaran online dengan baik. Sehingga proses pembelajaran tidak terlaksana dengan baik. Di SDN 109 Pekanbaru, pada penggunaan media pembelajaran online, guru mengalami kesulitan. Kesulitan merupakan suatu kondisi dimana gejala atau hambatan dan penghalang tercapainya suatu keinginan. Dalam kamus besar Bahasa Indonesia kesulitan berarti halangan, rintangan, faktor atau keadaan yang membatasi, menghalangi atau mencegah pencapaian sasaran atau tujuan (Ruslan, 2016).

\section{SIMPULAN}

Media pembelajaran online yang digunakan guru, WhatsApp, Google classroom dan Zoom. Akan tetapi, di dalam penggunaan media pembelajaran online, guru masih mengalami kesulitan-kesulitan, kesulitan yang di alami guru yaitu, guru kesulitan merancang media berbasis IT, mengoperasikan media berbasis IT, sarana dan prasarana yang tidak lengkap serta kesulitan terakhir guru adalah mengenai kreatifitas guru.

\section{DAFTAR PUSTAKA}

Alwi, S. (2017). Problematika guru dalam pengembangan media pembelajaran. Itqan, 8(2), 145-167. https: //ejurnal.iainlhokseumawe.ac.id/index.php/itqan/article/view/107.

Amalia, S. R., \& Puwaningsih, D. (2020). Pengaruh Self Regulated Learning Dan Web Course Berbantuan Google Classroom, Whatsapp Group Terhadap Pemahaman Konsep. AKSIOMA: Jurnal Program 
Studi Pendidikan Matematika, 9(4), 917. https://doi.org/10.24127/ajpm.v9i4.3009.

Amlin. (2021). Peningkatan Hasil Belajar Matematika dengan Media Google Classroom dan WhatsApp Sebagai Media Pembelajaran Daring pada Masa Pandemi Covid-19 bagi Siswa Kelas XII Busana 2 SMK Negeri 3 Baubau. Jurnal Penelitian Dan Pengembangan Pendidikan, 8(3), 431-437. https://doi.org/10.33394/jp.v8i3.3907.

Andel, S. A., de Vreede, T., Spector, P. E., Padmanabhan, B., Singh, V. K., \& Vreede, G. J. de. (2020). Do social features help in video-centric online learning platforms? A social presence perspective. Computers in Human Behavior, 113(April), 106505. https://doi.org/10.1016/j.chb.2020.106505.

Anugrahana, A. (2020). Hambatan, Solusi dan Harapan: Pembelajaran Daring Selama Masa Pandemi Covid-19 oleh Guru Sekolah Dasar. Scholaria: Jurnal Pendidikan Dan Kebudayaan, 10(3), 282-289. https://doi.org/10.24246/j.js.2020.v10.i3.p282-289.

Aras, L. (2019). Pengaruh Penggunaan Media Blok Pecahan Terhadap Minat Belajar Pada Mata Pelajaran Matematika Siswa Kelas III SD Kompleks Lariang Bangi Kecamatan Makassar Kota Makassar. JIKAP PGSD: Jurnal Ilmiah Ilmu Kependidikan, 3(1), 40. https://doi.org/10.26858/jkp.v3i1.8164.

Atikah, R.-, Prihatin, R. T., Hernayati, H., \& Misbah, J. (2021). Pemanfaatan Google Classroom Sebagai Media Pembelajaran Di Masa Pandemi Covid-19. Jurnal Petik, 7(1), 7-18. https://doi.org/10.31980/jpetik.v7i1.988.

Bakhtiyar, M. A. (2017). Promoting Blended Learning in Vocabulary Teaching Through. Nidhomul Haq:, 2(2), 106-112. https://doi.org/10.31538/ndh.v2i2.146.

Bhimani, N. T. (2020). Google Classroom platform for Physiology teaching in Medical College. Al Ameen Journal of Medical Sciences, 14(3), 295-303. https://youtu.be/L3zITJRZwT0.

Bressington, D. T., Wong, W. kit, Lam, K. K. C., \& Chien, W. T. (2018). Concept mapping to promote meaningful learning, help relate theory to practice and improve learning self-efficacy in Asian mental health nursing students: A mixed-methods pilot study. Nurse Education Today, 60(February 2017), 47-55. https://doi.org/10.1016/j.nedt.2017.09.019.

Dafit, F., \& Ramadan, Z. H. (2020). Pelaksanaan Program Gerakan Literasi Sekolah (GLS) di Sekolah Dasar. Jurnal Basicedu, 4(4), 1429-1437. https://doi.org/10.31004/basicedu.v4i4.585.

Dong, C., Cao, S., \& Li, H. (2020). Young Children's Online Learning During COVID-19 Pandemic: Chinese Parents' Beliefs and Attitudes. Children and Youth Services Review, 118. https://doi.org/10.1016/j.childyouth.2020.105440.

Endah, Y., \& Romadhiyana, K. S. (2021). Perbandingan Penggunaan Platform Google Classrom dan Grup Whatsapp Dalam Pembelajaran Online Selama Pandemi Covid-19. Jurnal Educatio FKIP UNMA, 7(1), 238-243. https://doi.org/10.31949/educatio.v7i1.934.

Fauziah, P. S., Kusdiana, A., \& S, R. W. (2018). Analisis Kesulitan Guru dalam Penggunaan Media Pembelajaran Bahasa Indonesia. Indonesian Journal of Primary Education, 2(1), 106. https://doi.org/10.17509/ijpe.v2i1.13754.

Habibah, R., Salsabila, U. H., Lestari, W. M., Andaresta, O., \& Yulianingsih, D. (2020). Pemanfaatan Teknologi Media Pembelajaran di Masa Pandemi Covid-19. Trapsila: Jurnal Pendidikan Dasar, 2(02), 1. https://doi.org/10.30742/tpd.v2i2.1070.

Haqien, D., \& Rahman, A. A. (2020). Use of Zoom Meetings for the Learning Process during the Covid-19 $\begin{array}{llll}\text { Pandemic. SAP Artikel Pendidikan), } & \text { (Susunan }\end{array}$ https://journal.uhamka.ac.id/index.php/uicell/article/view/6290.

Harahap, S. A., Dimyati, D., \& Purwanta, E. (2021). Problematika Pembelajaran Daring dan Luring Anak Usia Dini bagi Guru dan Orang tua di Masa Pandemi Covid 19. Jurnal Obsesi : Jurnal Pendidikan Anak Usia Dini, 5(2), 1825-1836. https://doi.org/10.31004/obsesi.v5i2.1013.

Herliandry, L. D., Nurhasanah, Suban, M. E., \& Heru, K. (2020). Transformasi Media Pembelajaran Pada Masa Pandemi Covid-19. Jurnal Teknologi Pendidikan, 22(1), 65-70. http://ejournal.kopertais4.or.id/sasambo/index.php/alhikmah/article/view/3905.

Hussein, E., Daoud, S., Alrabaiah, H., \& Badawi, R. (2020). Exploring undergraduate students' attitudes towards emergency online learning during COVID-19: A case from the UAE. Children and Youth Services Review, 119(August), 105699. https://doi.org/10.1016/j.childyouth.2020.105699.

Hwang, G. J., Wang, S. Y., \& Lai, C. L. (2020). Effects of a social regulation-based online learning framework on students' learning achievements and behaviors in mathematics. Computers and Education, 160, 104031. https://doi.org/10.1016/j.compedu.2020.104031.

Ismawati, D., \& Prasetyo, I. (2020). Efektivitas Pembelajaran Menggunakan Video Zoom Cloud Meeting pada Anak Usia Dini Era Pandemi Covid-19. Jurnal Obsesi : Jurnal Pendidikan Anak Usia Dini, 5(1), 665. https://doi.org/10.31004/obsesi.v5i1.671.

Jalinus, N. dan A. (2016). Media dan Sumber Pembelajaran. Kencana.

Kamiludin, K., \& Suryaman, M. (2017). Problematika pada pelaksanaan penilaian pembelajaran Kurikulum 
2013. Jurnal Prima Edukasia, 5(1), 58-67. https://doi.org/10.21831/jpe.v5i1.8391.

Kkese, E. (2020). McGurk effect and audiovisual speech perception in students with learning disabilities exposed to online teaching during the COVID-19 pandemic. Medical Hypotheses, 144(July), 110233. https://doi.org/10.1016/j.mehy.2020.110233.

Kostiainen, E., Ukskoski, T., Ruohotie-Lyhty, M., Kauppinen, M., Kainulainen, J., \& Mäkinen, T. (2018). Meaningful learning in teacher education. Teaching and Teacher Education, 71, 66-77. https://doi.org/10.1016/j.tate.2017.12.009.

Kusuma, J. W., \& Hamidah, H. (2020). Perbandingan Hasil Belajar Matematika Dengan Penggunaan Platform Whatsapp Group Dan Webinar Zoom Dalam Pembelajaran Jarak Jauh Pada Masa Pandemik Covid 19. JIPMat, 5(1). https://doi.org/10.26877/jipmat.v5i1.5942.

Lage-Cala, S., Folgueras-Díaza, M. B., Alonso-Hidalgoa, M., García-Menéndezb, D., \& Fernández-Garcíab, F. J. (2020). Investigation of the effectiveness of online learning tools for energy performance certificates preparation. Energy Reports, 6, 609-614. https://doi.org/10.1016/j.egyr.2019.09.034.

Lestari, I. D., Halimatusha'diah, \& Puji Lestari, F. A. (2018). Penggunaan Media Audio, Visual, Audiovisual, dalam Meningkatkan Pembelajaran kepada Guru-guru. Jurnal PkM Pengabdian Kepada Masyarakat, 1(01), 55. https://doi.org/10.30998/jurnalpkm.v1i01.2361.

Lounard Syaulan Sahelatua, L. V. dan M. (2018). Kendala Guru Memanfaatkan Media It Dalam Pembelajaran Di Sdn 1 Pagar Air Aceh Besar. Ilmiah Pendidikan Guru Sekolah Dasar, 3(2), 131140. http://www.jim.unsyiah.ac.id/pgsd/article/view/8579.

Marharjono, M. (2020). Manfaat Pembelajaran Sejarah Menggunakan Google Classroom Pada Masa Pandemi Covid-19. Ideguru: Jurnal Karya Ilmiah Guru, 5(1), 56-63. https://doi.org/10.51169/ideguru.v5i1.155.

Marsiding, Z. (2021). Efektifitas Penggunaan Media Zoom Terhadap Pembelajaran Pada Masa Pandemi Covid-19. Jurnal Ilmiah Pranata Edu, 2(1), 33-39. https://doi.org/10.36090/jipe.v2i1.931.

Mishra, D. L., Gupta, D. T., \& Shree, D. A. (2020). Online Teaching-Learning in Higher Education during Lockdown Period of COVID-19 Pandemic. International Journal of Educational Research Open, August, 100012. https://doi.org/10.1016/j.ijedro.2020.100012.

Mubarak, M. R., Wahdah, N., Ilmiani, A. M., \& Hamidah, H. (2020). Zoom Cloud Meeting: Media Alternatif dalam Pembelajaran Maharah Kalam di Tengah Wabah Virus Corona (Covid-19). Arabiyatuna: Jurnal Bahasa Arab, 4(2), 211. https://doi.org/10.29240/jba.v4i2.1445.

Muqsith, M. K. A., \& Zainiyati, H. S. (2021). Studi Komparasi Penggunaan WhatsApp dan Schoology Terhadap Hasil Belajar Di Masa Darurat. Jurnal Pendidikan Edutama, 8(1), 57. https://doi.org/10.30734/jpe.v8i1.1033.

Muskania, R., \& Zulela MS. (2021). Realita Transformasi Digital Pendidikan di Sekolah Dasar Selama Pandemi Covid-19. Jurnal Pendidikan Dasar Nusantara, 6(2), 155-165. https://doi.org/10.29407/jpdn.v6i2.15298.

Nirfayanti, N., \& Nurbaeti, N. (2019). Pengaruh Media Pembelajaran Google Classroom Dalam Pembelajaran Analisis Real Terhadap Motivasi Belajar Mahasiswa. Proximal Jurnal Penelitian Matematika Dan Pendidikan Matematika, 2(1), 50-59. https://ejournal.my.id/proximal/article/view/211.

Oyedotun, T. D. (2020). Sudden change of pedagogy in education driven by COVID-19: Perspectives and evaluation from a developing country. Research in Globalization, 2(June), 100029. https://doi.org/10.1016/j.resglo.2020.100029.

Pane, A., \& Dasopang, M. D. (2017). Belajar Dan Pembelajaran. FITRAH:Jurnal Kajian Ilmu-Ilmu Keislaman, 3(2), 333. https://doi.org/10.24952/fitrah.v3i2.945.

Patricia, A. (2020). College Students' Use and Acceptance of Emergency Online Learning Due to COVID-19. International Journal of Educational Research Open, 100011. https://doi.org/10.1016/j.ijedro.2020.100011.

Pentury, H. J. (2017). Pengembangan Kreativitas Guru dalam Pembelajaran Kreatif Pembelajaran Bahasa Inggris. Jurnal Ilmu Kependidikan, 4(3), 265-272. http://dx.doi.org/10.30998/fjik.v4i3.1923.

Pratama, H., \& Yusro, A. C. (2016). Implementasi WhatsApp Mobile Learning Untuk Meningkatkan Hasil Belajar Mahasiswa Pokok Bahasan Pengenalan Komponen Elektronika. Jurnal Pendidikan Fisika Dan Keilmuan (JPFK), 2(2), 65. https://doi.org/10.25273/jpfk.v2i2.696.

Puspita, A., Kurniawan, A. D., \& Rahayu, H. M. (2017). Pengembangan Media Pembelajaran Booklet Pada Materi Sistem Imun Terhadap Hasil Belajar Siswa Kelas Xi Sman 8 Pontianak. Jurnal Bioeducation, 4(1), 64-73. https://doi.org/10.29406/524.

Putranti, N. (2013). Cara Membuat Media Pembelajaran Online. Jurnal Pendidikan Informatika dan Sains, 2(2), 139-147. http://dx.doi.org/10.31571/saintek.v2i2.224.

Putria, H., Maula, L. H., \& Uswatun, D. A. (2020). Analisis Proses Pembelajaran dalam Jaringan (DARING) 
Masa Pandemi Covid- 19 Pada Guru Sekolah Dasar. Jurnal Basicedu, 4(4), 861-870. https://doi.org/10.31004/basicedu.v4i4.460.

Rahartri. (2019). "Whatsapp" Media Komunikasi Efektif Masa Kini (Studi Kasus Pada Layanan Jasa Informasi Ilmiah di Kawasan Puspiptek). Visi Pustaka, 21(2), 147-156. https://doi.org/10.37014/visi\%20pustaka.v21i2.552.

Rahayu, A. D., \& Haq, M. S. (2020). Sarana Dan Prasarana Dalam Mendukung Pembelajaran Daring Pada Masa Pandemi Covid-19. Jurnal Inspirasi Manajemen Pendidikan, 9(1), 186-199. https://ejournal.unesa.ac.id/index.php/inspirasi-manajemenpendidikan/article/view/38623/34138.

Rahmanto, M. A., \& Bunyamin. (2020). Efektivitas Media Pembelajaran Daring Melalui Google Classroom. Jurnal Pendidikan Islam, 11(November), 119-135. https://doi.org/10.22236/jpi.v11i2.5974.

Rusli, R., Rahman, A., \& Abdullah, H. (2020). Student perception data on online learning using heutagogy approach in the Faculty of Mathematics and Natural Sciences of Universitas Negeri Makassar, Indonesia. Data in Brief, 29, 105152. https://doi.org/10.1016/j.dib.2020.105152.

Sahu, P. (2020). Closure of Universities Due to Coronavirus Disease 2019 (COVID-19): Impact on Education and Mental Health of Students and Academic Staff. Cureus, 2019(4), 4-9. https://doi.org/10.7759/cureus.7541.

Salamah, W. (2020). Deskripsi Penggunaan Aplikasi Google Classroom dalam Proses Pembelajaran. Jurnal $\begin{array}{llll}\text { Penelitian Dan Pengembangan } & \text { P33-538. }\end{array}$ http://dx.doi.org/10.23887/jppp.v4i3.29099.

Setiawan, A. R. (2019). Pembelajaran Tematik Berorientasi Literasi Saintifik. Jurnal Basicedu, 4(1), 51-69. https://doi.org/10.31004/basicedu.v4i1.298.

Sourial, N., Longo, C., Vedel, I., \& Schuster, T. (2018). Daring to draw causal claims from non-randomized studies of primary care interventions. Family Practice, 35(5), 639-643. https://doi.org/10.1093/fampra/cmy005.

Sugiyono. (2017). Metode Penelitian Kuantitatif, Kualitatif, dan R\&D. Alfbeta.

Wahyono, P., Husamah, H., \& Budi, A. S. (2020). Guru profesional di masa pandemi COVID-19: Review implementasi, tantangan, dan solusi pembelajaran daring. Jurnal Pendidikan Profesi Guru, 1(1), 51-65. https://doi.org/10.22219/jppg.v1i1.12462.

Wahyuningsih, K. S., Hindu, U., Gusti, N. I., \& Sugriwa, B. (2021). Problematika Pembelajaran Daring di Masa Pandemi Covid-19 di SMA Dharma Praja Denpasar. 24(1), 107-118. https://ejournal.ihdn.ac.id/index.php/PJAH/article/view/2185. 